\title{
INCIDENCE OF FUNGAL DISEASES OF TOMATO IN SEED PRODUCING FIELDS
}

\author{
Zuparova Dilobar Mirakbarovna \\ Independent Researcher, Department of Agrobiotechnology, Tashkent State Agrarian University; \\ Research Officer Center of Genomics and Bioinformatics at Academy Sciences of Uzbekistan, \\ Tashkent, Uzbekistan
}

\author{
Ablazova Mokhichehra Mirakbarovna \\ Senior Teacher of the Department of Plant Protection, Tashkent State Agrarian University, \\ Tashkent, Uzbekistan
}

\author{
Zuparov Mirakbar Abzalovich \\ Associate Professor of the Department Agrobiotechnology, Tashkent State Agrarian University, \\ Tashkent, Uzbekistan
}

Article DOI: https://doi.org/10.36713/epra6240

\begin{abstract}
The article presents research results conducted on the study of the spread and development of fungal diseases in tomato fields for seed production in the condition of Tashkent region.
\end{abstract}

KEYWORDS: disease, fungi, alternaria, septoria, phytophthora, fusarium, seed, powdery mildew, gray mold.

\section{INTRODUCTION}

The most reliable guarantee of high yields from vegetable crops is healthy and best quality seeds. Seed quality is affected by a number of factors, among which are primarily diseases caused by fungi.

The occurrence of fungal diseases in agricultural crops in the fields to produce seeds and their development in these fields negatively affect not only the yield of seeds, but also their quality. Seeds collected from infected plants are too small in size, shrivelled and have a very low germination capacity. The most dangerous aspect of this case is that seeds harvested from diseased plants are a source of infection, and when they are used for planting it can lead to the emergence and spread of the diseases in new fields. Seedlings germinated from such seeds are weak and stunted, slow in growth and development. They are susceptible to the stresses of the external environment, especially to pests and diseases.

Tomato is one of the most widely grown vegetable crops in our republic. Tomato seeds produced in the country do not meet the needs of the vegetable growing industry. The main reason for this is that there are not enough seed producing farms to produce not only tomato seeds but also other vegetable crops, and the seed production in these existing farms does not meet the selection requirements. It is important to study the spread and development of diseases and identify their pathogens in the development of controlling measures for tomato diseases $[1,3,4,6]$.

\section{MATERIALS AND METHODS}

In order to study and solve the above problems, research work was carried out in 2017-2020 on the identification of the incidence and development of 


\section{EPRA International Journal of Research and Development (IJRD)

fungal diseases of tomatoes in the fields for seed production on the farms in Tashkent region. For this purpose, the pathogens and development of diseases in these farms were identified and phytopathological and mycological analysis of the samples of infected tomato plants and their seeds collected from the disease spread fields was performed in the laboratory of the Department of Agrobiotechnology of Tashkent State Agrarian University.

Incidence of fungal diseases of tomato plant has been calculated according to this formulae:

here,

$$
\mathrm{P}=\frac{100 \times n}{N}
$$

$P$ - disease incidence, $\%$;

$N$ - total number of surveyed plants;

$n$ - number of plants with disease symptoms [2].

Severity of diseases in tomato plant has been determined on the base of a 5-score scale method [2].

Here:

score

Percentage (\%)

$$
\begin{aligned}
& 0 \quad-\quad 0 \text { healthy plant; } \\
& 1-10 \% \text { infected plant; } \\
& 2-11-25 \% \text { infected plant; } \\
& 3 \text { - 26-50\% infected plant; } \\
& 4 \quad-\text { over } 50 \% \text { infected plant. }
\end{aligned}
$$

For the calculation of the expression with scores of the development level of tomato diseases in the percentage, the following formulae has been used:

Here,

$$
R=\frac{\left(\sum a \times b\right)}{N \times k},
$$

$\boldsymbol{R}$ - Severity of the disease, \%;

$\boldsymbol{\Sigma} \boldsymbol{a} \cdot \boldsymbol{b}$ - the sum of multiplication of the number of infected plants (a) with respective scores $(\boldsymbol{b})$;

$\boldsymbol{N}$ - total number of surveyed plants (healthy and infected);

$\boldsymbol{K}$ - number of scores in the scale [2].

A moisture chamber method was used to isolate pure cultures of fungi from diseased tomato plants and seeds. To do this, filter paper was placed on the bottom of a Petri dish, and sterilized in an autoclave for 30 minutes at a temperature of $121^{\circ} \mathrm{C}$ under 1 atmosphere pressure, and a moisture chamber was prepared. The parts and seeds of the tomato plant to be inspected were cleaned of microorganisms by sterilizing their outer parts. For sterilization, the plant part was immersed in $1 \%$ sodium hypochlorite solution for $0,5-1 \mathrm{~min}$, then washed 3-4 times with sterilized water. The filter papers on the Petri plates were then moistened with sterilized water in front of the alcohol lamp flame and the plant was cut into $1-3 \mathrm{~cm}$ pieces using a scalpel heated in the flame and were placed by 4-6 pieces on each plate. Petri dishes with plant parts were placed in thermostats with a temperature of $24-26^{\circ} \mathrm{C}$. From the third day, Petri dishes were observed and fungal mycelia or spores formed on the surface of the plant parts were inoculated into the oblique wort agar medium in the test tube. After the fungi in the test tube had grown well, its type was identified [5].

\section{RESULTS AND DISCUSSION}

The study identified six diseases caused by fungi in open fields of tomato. These are Alternaria, Botrytis, Septoria, Powdery mildew, Phytophthora, and Fusarium wilt (Table 1).

The spread and development of this disease occurred differently in the fields of Tashkent region. Fusarium and Alternaria diseases were mostly recorded than the remaining diseases, their spread constituted $42,8-55,3 \%$ and $32,8-46,7 \%$ and the development was $23,7-31,6 \%$ and $19,3-26,4 \%$ respectively. Powdery mildew disease of tomato plant was observed only for one year. It was firstly found in 2018 on the farm "Yahyo hoji" in Parkent district and its incidence made $1,4 \%$ while the development was found to be $0,8 \%$. 
$\begin{array}{lr}\text { SJIF Impact Factor: 7.001| ISI I.F.Value:1.241| Journal DoI: 10.36713/epra2016 } & \text { ISSN: 2455-7838(Online) } \\ \text { EPRA International Journal of Research and Development (IJRD) }\end{array}$

Volume: 6 | Issue: 1 | January $2021 \quad$ - Peer Reviewed Journal

Table-1

The Spread of Fungal Diseases of Tomato in the Fields of Tashkent Region

\begin{tabular}{|c|c|c|c|c|c|c|c|c|c|c|c|}
\hline \multirow[b]{3}{*}{ № } & \multirow{3}{*}{$\begin{array}{l}\text { Tomato } \\
\text { diseases }\end{array}$} & \multirow{3}{*}{ Disease agent } & \multicolumn{9}{|c|}{ Incidence and severity of diseases over the years } \\
\hline & & & \multicolumn{3}{|c|}{ In 2017} & \multicolumn{3}{|c|}{ In 2018} & \multicolumn{3}{|c|}{ In 2019} \\
\hline & & & $\begin{array}{l}\text { Spread of } \\
\text { disease, } \\
\% \\
\end{array}$ & $\begin{array}{l}\text { Severity of } \\
\text { disease, } \%\end{array}$ & $\begin{array}{l}\text { Disease } \\
\text { index, } \%\end{array}$ & $\begin{array}{c}\text { Spread of } \\
\text { disease, } \\
\% \\
\end{array}$ & $\begin{array}{l}\text { Severity of } \\
\text { disease, } \%\end{array}$ & $\begin{array}{c}\text { Disease } \\
\text { index, } \\
\% \\
\end{array}$ & $\begin{array}{c}\text { Spread of } \\
\text { disease, } \\
\% \\
\end{array}$ & $\begin{array}{l}\text { Severity of } \\
\text { disease, } \%\end{array}$ & $\begin{array}{c}\text { Disease } \\
\text { index, } \\
\% \\
\end{array}$ \\
\hline 1. & Alternaria & $\begin{array}{l}\text { Alternaria solani (Ell. et } \\
\text { Mart.) Sorauer }\end{array}$ & 32,8 & 19,3 & 6,3 & 46,7 & 26,4 & 12,3 & 39,4 & 22,8 & 9,0 \\
\hline 2. & $\begin{array}{c}\text { Botrytis or gray } \\
\text { rot }\end{array}$ & Botrytis cinerea Pers. & 17,7 & 10,1 & 1,8 & 7,6 & 4,5 & 0,3 & 12,6 & 7,3 & 0,9 \\
\hline 3. & $\begin{array}{l}\text { Septoria or white } \\
\text { spot }\end{array}$ & Septoria lycopersici Speg. & 5,3 & 1,9 & 0,1 & 13,2 & 4,0 & 0,5 & 8,2 & 2,1 & 0,2 \\
\hline 4. & Powdery mildew & $\begin{array}{c}\text { Erysiphe communis Grex. } \\
\text { or Oidium lycopersicum } \\
\text { Cooke et Mass. }\end{array}$ & - & - & - & 1,4 & 0,8 & 0,01 & - & - & - \\
\hline 5. & Phytophthora & $\begin{array}{c}\text { Phytophtora infestans De } \\
\text { Bary }\end{array}$ & 14,1 & 6,5 & 0,9 & 4,9 & 2,9 & 0,1 & 7,8 & 3,5 & 0,3 \\
\hline 6. & Fusarium & $\begin{array}{c}\text { Fusarium oxysporum } f . \\
\text { lycopersici (Sacc.) Snyd. } \\
\text { et Hans. }\end{array}$ & 42,8 & 23,7 & 10,1 & 55,3 & 31,6 & 17,5 & 49,1 & 28,4 & 13,9 \\
\hline
\end{tabular}




\section{EPRA International Journal of Research and Development (IJRD) \\ Volume: 6 | Issue: 1 | January 2021 \\ - Peer Reviewed Journal}

The diseases botrytis and phytophthora stopped developing in the infected organs of tomatoes with an increase in air temperature and a decrease in air humidity. When they were observed, their spread rate made $7,6-17,7 \%$ and $2,9-14,1 \%$ and their development $4,5-10,1 \%$ and $2,9-6,5 \%$ respectively.

Septoria disease of tomato was noted to infect only the leaves of the plant and the prevalence of the disease was $5,3-13,2 \%$ while the development was $1,9-4,0 \%$. When disease incidence in tomato plants was analyzed by the years, the rate varied depending on the type of diseases. In 2017, there was much more precipitation which led to higher spread and development of the diseases botrytiosis $(17,7 \%$ and $10,1 \%)$ and phytophthora than in previous years. It was noted that the prevalence and development of alternariosis, septoria and fusarium wilt diseases were higher in 2018 and 2019, when air humidity was relatively lower during the growing season.

\section{CONCLUSION}

The fungal diseases alternaria, gray mold rot, septoria, powdery mildew, phytophthora, fusarium wilt were recorded in the fields of tomato for the production of seeds.

Among the identified diseases of tomato, fusarium wilt and alternaria diseases were found the most common and widespread in seed-producing fields.

\section{REFERENCES}

1. Avakyan G.V. Species composition of fungi, isolated from the seeds of vegetable crops of Solanaceae family. Agrogitutyun, No 4, 2002. p.157.

2. Dementyeva M.I. Phytopathology. Moscow: Agropromizdat, 1985.397 p.

3. Dinler H., Günay M. Determination of fungal agents in some vegetables seeds in greenhouse production areas in Uşak Province. International Journal of Agriculture and Forestry. 2018, Vol. 8, No 2. pp.83-91.

4. Hamim I. Mohanto D.C., Sarker M.A., Ali M.A. Effect of seed borne pathogens on germination of some vegetable seeds. Journal of Phytopathology and pest management, 2014. Vol. 1, No 1. pp. 34-51.

5. Khasanov B.A., Safarov A.A., Khamiraev U.K., Sherimbetov A.G., Mycology. Tashkent: TashSAU publishing house, 2020. $152 \mathrm{p}$.

6. Mancini V., Romanazzi G. Seed treatments to control seedborne fungal pathogens of vegetable crops. Pest ManagSci 2014, Vol. 70, No 6, pp. 860868. doi: 10.1002/ps.3693

7. Schtock D.A. Fungi in the seeds of crops in Uzbekistan. Tashkent: Fan, 1990. 168 p.

8. Kamilov, S.G., Nuraliev, K.K., Sattarova, R.K., Khakimov, A.A. The history of mycology and phytopathology development in Uzbekistan. Mikologiya i Fitopatologiya, 2020, 54(5), pp. 313319
9. Khakimov A.A., Omonlikov A.U., Utaganov S.B. Current status and prospects of the use of biofungicides against plant diseases. GSC Biological and Pharmaceutical Sciences. Vol. 13, Issue 3, 2020, pp. 119-126. https://doi.org/10.30574/gscbps.2020.13.3.0403

10. Mamiev M.S., Khakimov A.A., Zuparov M.A., Rakhmonov U.N. Effectiveness of different fungicides in controlling botrytis grey mould of tomato. 1st International Conference on Energetics, Civil and Agricultural Engineering 2020" (ICECAE 2020), 14-16 October 2020, Tashkent, Vol. 614, 012112

11. Mamiev, M., Korolev, N., and Elad, Y. (2013). Resistance to polyoxin $A L$ and other fungicides in Botrytis cinerea collected from sweet basil crops in Israel. European Journal of Plant Pathology, 137(1), 79-91.

12. Zuparov M.A., Khakimov A.A., Mamiev M.S., Allayarov A.N. In vitro efficacy testing of fungicides on Botrytis cinerea causing gray mold of tomato. International Journal on Emerging Technologies, 2020, 11(5), pp. 50-55. 